\section{CARDIOVASCULAR EFFECTS OF A STRENGTH TEST (1RM) IN PREHYPERTENSIVE SUBJECTS}

\author{
EFEITOS CARDIOVASCULARES DE UM TESTE DE FORÇA (1RM) EM SUJEITOS PRÉ-HIPERTENSOS
}

EFECTOS CARDIOVASCULARES DE UN TEST DE FUERZA (1RM) EN SUJETOS PRE-HIPERTENSOS

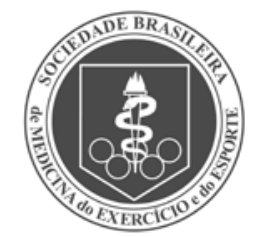

Original Article ARtigo Original Artículo Original
Cleberson Dias Lima' (Physician)

Paula Felippe Martinez

(Physiotherapist)

Camila Souza de Morais

(Nutritionist)

Fernando Sérgio Silva Barbosa

(Physiotherapist)

Gabriel Elias Ota

(Physical Education Professional)

Silvio Assis de Oliveira Júnior ${ }^{1,3}$

(Physiotherapist)

1. Universidade Federal do Mato Grosso do Sul, Graduate Studies in Health and Development in the Midwest Region, Campo Grande, MS, Brazil.

\section{Correspondence:}

Cleberson Dias Lima, Universidade Estadual de Mato Grosso do Sul, Coordenação do Curso de Medicina. Unidade Campo Grande. 79115-898. Campo Grande, MS, Brazil. cleberson07@hotmail.com

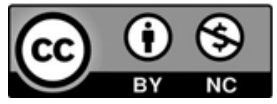

\begin{abstract}
Introduction: Physical exercise promotes positive physiological adaptations, reducing the risk of developing cardiovascular diseases and promoting greater autonomic control of heart rate and reduction in pressure levels. Objective: To compare the behavior of arterial pressure and autonomic heart rate modulation in the 1-repetition maximum knee extension test, performed on the 45-degree leg press machine in normotensive and prehypertensive subjects. Methods: Twenty-four male volunteers were assessed. Blood pressure (BP) and heart rate variability (HRV) were evaluated at rest, immediately after the maximum load achieved and during the 10, 20, 30 and 40-minute recovery phases. Statistical analyses were obtained using SigmaStat 3.5 software and a level of significance of $5 \%$. Results: Mean and standard deviation were used to identify 12 normotensive patients $(\mathrm{N})$ aged $=25.5 \pm 5.7$ years; height $=174.3 \pm 6.6 \mathrm{~cm} ; \mathrm{BMI}=24.9 \pm 2.4 ; \mathrm{SBP}$ on average $=112.6 \pm 5.6$ $\mathrm{mmHg}$ and 12 prehypertensive $(\mathrm{PH})$ patients aged $=29.8 \pm 6.5$ years; height $=175.7 \pm 6.7 \mathrm{~cm} ; \mathrm{BMI}=27.8 \pm 6.5$; mean SBP $=131.1 \pm 3.2 \mathrm{mmHg}$. There was a statistical difference in the pNN50 index (\%) at rest ( $\mathrm{PH}=1.13 \pm 0.66$ and $\mathrm{N}=1.58 \pm 0.35)$ and in the $\mathrm{LF} / \mathrm{HF}$ index, also at rest $(\mathrm{PH}=0.18 \pm 0.29$ and $\mathrm{N}=-0.18 \pm 0.36)$. Conclusion: The one-repetition maximum (1RM) test did not promote cardiovascular risk in the prehypertensive group during its execution, with double product results lower than $30,000 \mathrm{mmHg} . \mathrm{bpm}$, demonstrating lower cardiac overload. Moreover, HRV exhibited similarity in sympathetic-vagal behavior, in the time/frequency domain, between the groups. Level of Evidence III; Study Case-control.
\end{abstract}

Keywords: Resistance training; Hypertension; Prehypertension.

\section{RESUMO}

Introdução: O exercício físico promove adaptações fisiológicas de caráter positivo, diminuindo os riscos de desenvolvimento de doenças cardiovasculares, além de promover um maior controle autonômico da frequência cardíacae redução nos níveis pressóricos. Objetivo: Comparar o comportamento da pressão arterial e da modulação autonômica da frequência cardíaca no teste de uma repetição máxima de extensão de joelhos, realizado no aparelho de Leg press $45^{\circ} \mathrm{em}$ sujeitos normotensos e pré-hipertensos. Métodos: Foram avaliados 24 voluntários do sexo masculino. Foi feita a avaliação da pressão arterial (PA) e da variabilidade da frequência cardíaca (VFC) no momento de repouso, imediatamente após a carga máxima alcançada e durante as fases de 10, 20, 30 e 40 minutos de recuperação. As análises estatísticas foram obtidas através do software SigmaStat 3.5 e nível de significância igual a 5\%. Resultados: A média e o desvio padrão foram utilizados para identificação de 12 normotensos $(N)$ com idade $=25,5 \pm 5,7$ anos; altura $=$ $174,3 \pm 6,6 \mathrm{~cm} ; I M C=24,9 \pm 2,4 ;$ PAS em média $=112,6 \pm 5,6 \mathrm{mmHg}$ e 12 pré-hipertensos $(P H)$ com idade $=29,8 \pm 6,5$ anos; altura $=175,7 \pm 6,7 \mathrm{~cm} ; \mathrm{IMC}=27,8 \pm 6,5 ; P A S$ em média $=131,1 \pm 3,2 \mathrm{mmHg}$. Houve diferença estatística no indice pNN50 (\%) no momento repouso ( $P H=1,13 \pm 0,66 \mathrm{eN}=1,58 \pm 0,35)$ e no índice LF/HFigualmente no momento repouso ( $P H=0,18 \pm 0,29$ e $N=-0,18 \pm 0,36)$. Conclusão: $O$ teste de uma repetição máxima (1RM) não promoveu risco cardiovascular no grupo pré-hipertenso durante sua execução, com resultados de duplo produto menor que $30.000 \mathrm{mmHg} .6 p m$, demonstrando menor sobrecarga cardíaca, e a VFC apresentou similaridade no comportamento simpático-vagal no domínio do tempo e frequência entre os grupos. Nível de evidência III; Estudo Caso controle.

Descritores: Treinamento de resistência; Hipertensão; Pré-hipertensão.

\section{RESUMEN}

Introducción: El ejercicio físico promueve adaptaciones fisiológicas de carácter positivo, disminuyendo los riesgos de desarrollo de enfermedades cardiovasculares, además de promover un mayor control autonómico de la frecuencia cardíaca y reducción en los niveles presóricos. Objetivo: Comparar el comportamiento de la presión arterial y de la modulación autonómica de la frecuencia cardíaca en el test de una repetición máxima de extensión de rodillas, realizado en el aparato de Leg press $45^{\circ}$ en sujetos normotensos y pre-hipertensos. Métodos: Fueron evaluados 24 voluntarios del sexo masculino. Fue hecha la evaluación de la presión arterial (PA) y de la variabilidad de la frecuencia cardíaca (VFC) en el momento de reposo, inmediatamente después de la carga máxima alcanzada y durante las fases de 10,20, 30 y 40 minutos de recuperación. Los análisis estadísticos fueron obtenidos a través del software SigmaStat 3.5 y nivel de significancia igual a 5\%. Resultados: El promedio y la desviación estándar fueron utilizados para identificación de 12 normotensos $(N)$ con edad $=25,5 \pm 5,7$ años; altura $=174,3 \pm 6,6 \mathrm{~cm} ; I M C=24,9 \pm 2,4 ;$ PAS 
en promedio $=112,6 \pm 5,6 \mathrm{mmHg}$ y 12 pre-hipertensos $(\mathrm{PH})$ con edad $=29,8 \pm 6,5$ años; altura $=175,7 \pm 6,7 \mathrm{~cm} ; \mathrm{MC}$ $=27,8 \pm 6,5 ;$ PAS en promedio $=131,1 \pm 3,2 \mathrm{mmHg}$. Hubo diferencia estadística en el índice pNN50 (\%) en el momento reposo ( $P H=1,13 \pm 0,66$ y $N=1,58 \pm 0,35)$ yen el indice $L F / H F$ igualmente en el momento reposo ( $P H=0,18 \pm 0,29 y$ $N=-0,18 \pm 0,36)$. Conclusión: El test de una repetición máxima (1RM) no promovió riesgo cardiovascular en el grupo pre-hipertenso durante su ejecución, con resultados de doble producto menor que $30.000 \mathrm{mmHg} .6 p m$, demostrando menor sobrecarga cardíaca, y la VFC presentó similitud en el comportamiento simpático-vagal en el dominio del tiempo y frecuencia entre los grupos. Nivel de evidencia III; Estudio Caso control.

Descriptores: Entrenamiento de resistencia; Hipertensión; Prehipertensión.

\section{INTRODUCTION}

Prehypertension $(\mathrm{PH})$ is a condition in which systolic blood pressure (SBP) is $121-139 \mathrm{mmHg}$ and diastolic blood pressure (DBP) is $81-89 \mathrm{mmHg}$ and is closely associated with various cardiac alterations. ${ }^{1,2}$ In Brazil, surveys revealed that the prevalence of prehypertension is $36.8 \% .{ }^{3}$ Thus, national and international organizations have recommended the regular practice of physical exercise with appropriate load and guidance for both the prevention and the treatment of cardiovascular and metabolic diseases. ${ }^{4}$

Accordingly, although reflected in lower heart rate $(H R)$ variations, resistance exercises can produce an increase in blood pressure (BP) that is equivalent to or exceeds that of continuous aerobic exercise. The problem is accentuated at the moment resistance training exercises are prescribed because BP can increase according to load. Thus, BP levels are related to the required resistance, duration of muscle contraction, and recovery period..$^{5-7}$

In this context, Terra et al. (2008) demonstrated that resistance training promotes a change in $\mathrm{PH}$ by normalizing the BP levels in response to exercises with intensity of 60 to $80 \%$ of a one-repetition maximum (1RM) test. ${ }^{8}$

The prescription of resistance exercise is commonly guided by direct and indirect ways of measuring exercise intensity, which may show higher or lower accuracy. ${ }^{10}$ Predictive formulas or equations display accuracy limitations, as they are developed by regressive statistical methods, making them inaccurate and with a high probability of estimation error in addition to having a low association with cardiovascular variables. ${ }^{11,12}$ According to some authors, $8,13,14$ the 1 RM test promotes more pronounced changes in patients with $\mathrm{PH}$ than in normotensive individuals.

Given these considerations, the objective of this study was to compare BP and autonomic modulation of HR in the 1RM test of lower limbs in normotensive and prehypertensive subjects. As an initial hypothesis, we assumed that the cardiovascular responses would be larger in the prehypertension condition.

\section{METHODS}

\section{Nature of the study and sample}

This experimental, cross-sectional, and controlled study was performed at the Clínica Escola Integrada of the Integrated Health Institute. The sample consisted of 24 male adult participants, of whom 22 were university students and two were active soldiers, living in Campo Grande, Mato Grosso do Sul, Brazil. Inclusion criteria were having at least 3 months of experience in resistance training at a minimum frequency of three times a week. Voluntary users of medication or substances with cardiovascular effects who had a history of osteomyoarticular problems in the lower limbs were excluded from the study.

The volunteers signed an Informed Consent Form according to resoIution 466/2012 of the National Health Council. This study was approved by the Institutional Ethics Committee (CAAE: 52957916.8.0000.0021; opinion 1.432.755). After providing informed consent, the participants were invited to answer the Par-Q questionnaire to determine their individual readiness for physical activity. ${ }^{15}$

\section{Study design and analysis procedures}

The participants were divided into two experimental groups according to the cardiovascular assessment findings: the normotensive control group ( $\mathrm{N} ; \mathrm{n}=12$ ) and the prehypertensive experimental group $(\mathrm{PH} ; \mathrm{n}=12)$. For sample characterization, to classify the individuals as normotensive or hypertensive, prescreening was performed in situ in the volunteer's environment in accordance with the SBC guidelines. ${ }^{2}$

$\mathrm{BP}$ and $\mathrm{HR}$ were assessed by positioning the volunteers in supine position on a stretcher for 10 minutes without visual stimuli. After this period, a first measurement was performed using the indirect and oscillometric method. ${ }^{9}$

The HR variability (HRV) assessment was performed using beat-to-beat $H R$ recorded throughout the experiment with a sampling rate of 1,000 Hz using 1,000 consecutive R-R intervals.

The HRV analysis was performed by assessment of the time domain and frequency data. For the time domain, the variables used were standard deviation of the R-R intervals (SDNN), the square root of the mean square of the differences between successive R-R intervals (RMSSD), and percentage of adjacent RR intervals with duration difference $>50$ ms (pNN50). In the frequency domain, the total power of the frequency bands, very low frequency (VLF), low frequency (LF), high frequency (HF), and LF/HF ratio were analyzed. ${ }^{12}$

Kubios HRV analysis software version 2.2 was used to fit the intervals and calculate the indices.

For the anthropometric analysis, a tetrapolar bioimpedance Omron HBF-514C model scale was used to measure weight in kilograms, while height in centimeters was measured with a Wiso brand stadiometer. The body mass index (BMI) was calculated from the formula weight $(\mathrm{kg}) /$ height $\left(\mathrm{m}^{2}\right)$. The relative values (\%) of lean mass and body fat were also considered. A calculation was then performed to obtain the estimated 1RM test value using the formula validated by Brzycki (1993). ${ }^{16}$ The 1RM test was performed using a $45^{\circ}$ leg press apparatus following the protocol to perform the $1 \mathrm{RM}$ test with high reproducibility. ${ }^{17,18}$ Figure 1 illustrates the study's experimental design.

The participants were always evaluated in the morning to avoid interference of the circadian cycle. The laboratory temperature was maintained at $22-24^{\circ} \mathrm{C}$ and the relative humidity at $50-60 \%$. All volunteers were instructed not to perform strenuous physical exercise for 48 hours before the test, refrain from consuming stimulants or alcohol in the 24 hours prior to the test, avoid smoking 3 hours before, eat a light meal at least 2 hours before the assessment, and sleep at least 7-8 hours in the evening prior to the assessment.

\section{Statistical analysis}

The results are presented in a descriptive format through measures of centrality and variability. The HRV results were converted to a logarithm scale (log10) to ensure normal data distribution. Student's t-test for independent samples was used to analyze the demographic and anthropometric 


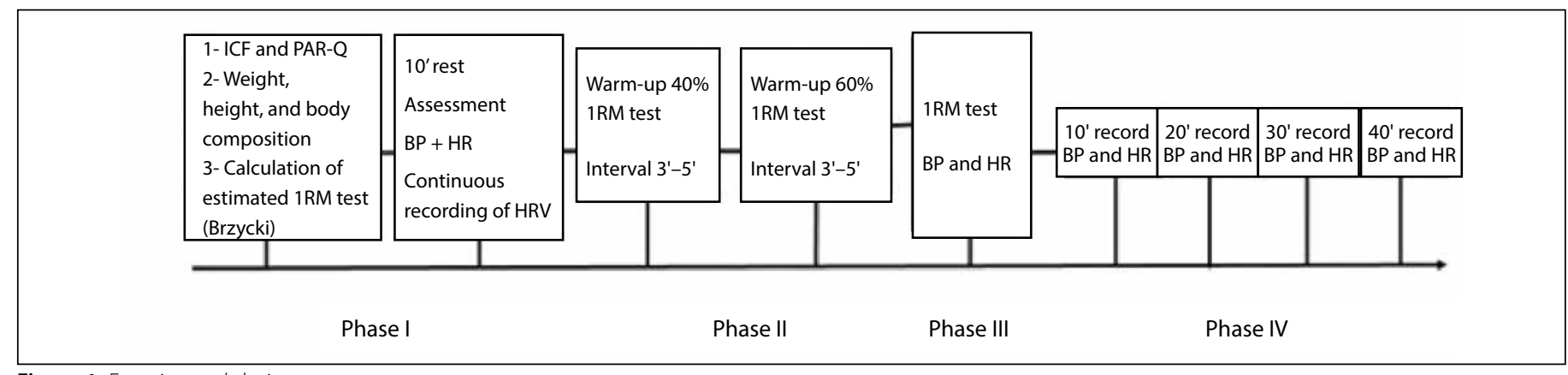

Figure 1. Experimental design.

characteristics. The evaluation of cardiovascular outcomes was performed with two-way repeated measures analysis of variance complemented by the Bonferroni multiple comparison test. The effect of the anthropometric composition as an intervening variable on HRV was assessed using the analysis of covariance technique and body fat measurements were adopted as covariates. The significance level was set at $5 \%$.

\section{RESULTS}

Table 1 presents the participants' general characteristics by group. The $\mathrm{PH}$ group showed higher $\mathrm{BMI}$ and body fat values and lower lean mass values than the $\mathrm{N}$ group ( $\mathrm{p}<0.05)$.

From a cardiovascular perspective, higher values of $\mathrm{HR}$, double product (DP), SBP, and DBP after the 1RM test were observed within the $\mathrm{N}$ group compared to the other moments of evaluation. In relation to $\mathrm{PH}$, a similar behavior was observed only for DP and SBP; HR and DBP were evaluated after the test with a reduction of these measures after 20 and 30 minutes of recovery, respectively. Compared with the $\mathrm{N}$ group, the $\mathrm{PH}$ group displayed higher values $(\mathrm{p}<0.05)$ of DP, SBP, and DBP in all moments of evaluation (Table 2).

Table 3 presents the measures of HRV in the time domain. No significant intergroup differences were observed for SDNN and RMSSD at

Table 1. Participants' general characteristics by group.

\begin{tabular}{c|c|c|c}
\hline \multirow{2}{*}{ Variable } & \multicolumn{2}{|c|}{ Group } & \multirow{2}{*}{ p-value } \\
\cline { 2 - 3 } & $\mathbf{N}$ & $\mathbf{P H}$ & \\
\hline Age (years) & $25.5 \pm 5.7^{\mathrm{a}}$ & $29.8 \pm 6.5^{\mathrm{a}}$ & 0.099 \\
\hline Height (cm) & $174.3 \pm 6.6^{\mathrm{a}}$ & $175.7 \pm 6.7^{\mathrm{a}}$ & 0.614 \\
\hline BMl $\left(\mathrm{kg} / \mathrm{m}^{2}\right)$ & $24.6 \pm 2.3^{\mathrm{a}}$ & $27.7 \pm 3.7^{\mathrm{b}}$ & 0.028 \\
\hline Fat (\%) & $19.71 \pm 4.05^{\mathrm{a}}$ & $24.69 \pm 5.99^{\mathrm{b}}$ & 0.031 \\
\hline Muscle (\%) & $40.30 \pm 2.10^{\mathrm{a}}$ & $36.86 \pm 3.49^{\mathrm{b}}$ & 0.010 \\
\hline Training time (months) & $43 \pm 38^{\mathrm{a}}$ & $96 \pm 84^{\mathrm{a}}$ & 0.079 \\
\hline Load - 1RM (Kg) & $301 \pm 62^{\mathrm{a}}$ & $369 \pm 85^{\mathrm{a}}$ & 0.055 \\
\hline
\end{tabular}

Values are expressed as mean \pm standard deviation; $\mathrm{N}$, normotensive group; $\mathrm{PH}$, prehypertensive group $\mathrm{BMI}$, body mass index; 1RM, one-repetition maximum test. a,bintergroup comparisons with statistically significant differences $(p<0.05)$ using Student's t-test for independent samples. any moment of the assessment. At rest, the $\mathrm{N}$ group presented a higher pNN50 value than the PH group. For group N, the pNN50 value was greater at rest than the other moments of assessment. There were no differences in the $\mathrm{PH}$ group at any moment of assessment.

Table 4 presents the measures of heart rate variability in the frequency domain. The $\mathrm{N}$ group showed lower value of LF/HF compared to the $\mathrm{PH}$ group in resting condition. In the assessment of moments, both groups showed elevation of the LF/HF after the 1RM test, which persisted until the end of the assessment. In both groups an elevation of the VLF values was observed after the test, with a reduction from 10 minutes of recovery, which persisted until the end of the assessment. When adjusting the initial values of LF/HF for the percentage of body fat, the groups were found to be similar to each other $(N,-0.18 \pm 0.04$; $\mathrm{PH}, 0.18 \pm 0.06, \mathrm{p}>0.05$; Figure 2).

\section{DISCUSSION}

Most published studies are related to acute and chronic cardiovascular responses during physical exercises..$^{19,20}$

The objective of this study was to compare the behavior of BP and autonomic modulation of HR during the 1RM test of lower limbs in normotensive and prehypertensive subjects. As an initial hypothesis, we assumed that the cardiovascular responses would be higher in the $\mathrm{PH}$ group than the $\mathrm{N}$ group. Although the results confirm this precept, there is no risk to the prehypertensive subjects in a clinical context since the DP values are below the reference parameters for cardiovascular risk. ${ }^{21}$

Nevertheless, studies on the hemodynamic response associated with the $1 \mathrm{RM}$ test remain scarce. The isolated analysis of $\mathrm{HR}$ is not reliable in cardiovascular safety to scale overload during physical exercise. Therefore, it is necessary to monitor SBP through the DP since HR $\times$ SBP indicates the actual consumption of oxygen by the myocardium. ${ }^{21}$

During resistance training, there is an increase in the DP at levels lower than those achieved by aerobic exercise because dynamic resistance exercise does not maintain constant intensity and leads to less oxygen consumption by the myocardium. ${ }^{22}$

Table 2. Measures of cardiovascular characterization according to group and assessment moment.

\begin{tabular}{|c|c|c|c|c|c|c|c|c|c|c|}
\hline \multirow{2}{*}{ Variable } & \multirow{2}{*}{ Group } & \multicolumn{6}{|c|}{ Moment } & \multicolumn{3}{|c|}{ Factor ( $p$ value) } \\
\hline & & Rest & Test & $10 \mathrm{~min}$ & $20 \mathrm{~min}$ & $30 \mathrm{~min}$ & $40 \mathrm{~min}$ & G & M & Int. \\
\hline \multirow{2}{*}{ HR (bpm) } & $\mathrm{N}$ & $59.0 \pm 7.7^{\mathrm{Aa}}$ & $119.8 \pm 18.3^{\mathrm{Ba}}$ & $65.3 \pm 11.3^{\mathrm{Aa}}$ & $63.9 \pm 9.5^{\mathrm{Aa}}$ & $63.8 \pm 7.9 \mathrm{Aa}$ & $59.6 \pm 8.1^{\mathrm{Aa}}$ & \multirow{2}{*}{0.056} & \multirow{2}{*}{$<0.001$} & \multirow{2}{*}{0.523} \\
\hline & $\mathrm{PH}$ & $64.7 \pm 8.7^{\mathrm{Aa}}$ & $131.2 \pm 15.6 \mathrm{Ca}$ & $74.2 \pm 11.4^{\mathrm{Bb}}$ & $73.2 \pm 10.4^{\mathrm{Bb}}$ & $68.0 \pm 11.4^{\mathrm{ABa}}$ & $69.0 \pm 11.9^{\mathrm{ABb}}$ & & & \\
\hline \multirow{2}{*}{$\mathrm{DP}(\mathrm{bpm} / \mathrm{mmHg})$} & $\mathrm{N}$ & $6739 \pm 889^{\mathrm{Aa}}$ & $16297 \pm 3900^{\mathrm{Ba}}$ & $7810 \pm 1761^{\mathrm{Aa}}$ & $7423 \pm 1240^{\mathrm{Aa}}$ & $7545 \pm 13933^{\mathrm{Aa}}$ & $6827 \pm 1200 \mathrm{Aa}$ & \multirow{2}{*}{0.001} & \multirow{2}{*}{$<0.001$} & \multirow{2}{*}{0.652} \\
\hline & $\mathrm{PH}$ & $8467 \pm 1023^{\mathrm{Ab}}$ & $20621 \pm 4356^{\mathrm{Bb}}$ & $9852 \pm 1781^{\mathrm{Ab}}$ & $9656 \pm 1401^{\mathrm{Ab}}$ & $8986 \pm 1413^{A b}$ & $9040 \pm 1769^{A b}$ & & & \\
\hline \multirow{2}{*}{$\mathrm{SBP}(\mathrm{mmHg})$} & $\mathrm{N}$ & $114.3 \pm 4.3^{\mathrm{Aa}}$ & $135.4 \pm 16.8^{\mathrm{Ba}}$ & $118.7 \pm 8.7^{\mathrm{Aa}}$ & $116.3 \pm 10.4^{\mathrm{Aa}}$ & $117.8 \pm 10.8^{\mathrm{Aa}}$ & $114.1 \pm 7.0^{\mathrm{Aa}}$ & \multirow{2}{*}{$<0.001$} & \multirow{2}{*}{$<0.001$} & \multirow{2}{*}{0.741} \\
\hline & $\mathrm{PH}$ & $131.2 \pm 3.2^{\mathrm{Ab}}$ & $155.9 \pm 17.5^{\mathrm{Bb}}$ & $132.5 \pm 7.9^{A b}$ & $132.1 \pm 6.4^{\mathrm{Ab}}$ & $132.4 \pm 6.1^{\mathrm{Ab}}$ & $130.6 \pm 6.6^{\mathrm{Ab}}$ & & & \\
\hline \multirow{2}{*}{$\mathrm{DBP}(\mathrm{mmHg})$} & $\mathrm{N}$ & $64.2 \pm 5.1^{\mathrm{Aa}}$ & $73.5 \pm 6.9^{\mathrm{Ba}}$ & $65.9 \pm 10.0^{\mathrm{Aa}}$ & $66.5 \pm 10.1^{\mathrm{Aa}}$ & $69.5 \pm 9.0^{\mathrm{ABa}}$ & $66.8 \pm 7.0^{\mathrm{Aa}}$ & \multirow{2}{*}{0.001} & \multirow{2}{*}{0.001} & \multirow{2}{*}{0.492} \\
\hline & $\mathrm{PH}$ & $75.8 \pm 8.1^{\mathrm{Ab}}$ & $87.5 \pm 8.6^{\mathrm{Cb}}$ & $81.3 \pm 8.7^{\mathrm{ABCb}}$ & $82.2 \pm 8.6^{\mathrm{BCb}}$ & $80.3 \pm 8.1^{\mathrm{ABb}}$ & $80.4 \pm 7.6^{\mathrm{ABb}}$ & & & \\
\hline
\end{tabular}

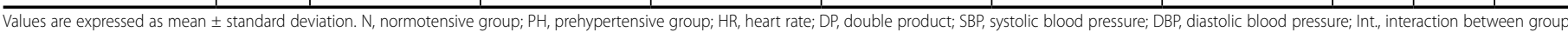

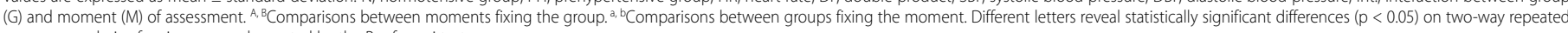
measures analysis of variance complemented by the Bonferroni test. 
Table 3. Measures of heart rate variability in the time domain by and assessment moment.

\begin{tabular}{|c|c|c|c|c|c|c|c|c|c|c|}
\hline \multirow{2}{*}{ Variable } & \multirow{2}{*}{ Group } & \multicolumn{6}{|c|}{ Moment } & \multicolumn{3}{|c|}{ Factor ( $p$ value) } \\
\hline & & Rest & Test & $10 \mathrm{~min}$ & $20 \mathrm{~min}$ & $30 \mathrm{~min}$ & $40 \mathrm{~min}$ & G & $M$ & Int. \\
\hline \multirow{2}{*}{ SDNN (ms) } & $\mathrm{N}$ & $1.90 \pm 0.17 \mathrm{Aa}$ & $1.90 \pm 0.17^{\mathrm{Aa}}$ & $2.14 \pm 0.12^{\mathrm{Ba}}$ & $2.05 \pm 0.15^{\text {Ba }}$ & $1.90 \pm 0.16^{\mathrm{Aa}}$ & $1.90 \pm 0.13^{\mathrm{Aa}}$ & \multirow{2}{*}{0.344} & \multirow{2}{*}{$<0.001$} & \multirow{2}{*}{0.947} \\
\hline & $\mathrm{PH}$ & $1.89 \pm 0.18 \mathrm{ABa}$ & $1.89 \pm 0.18^{\mathrm{ABa}}$ & $2.10 \pm 0.12^{\mathrm{Ca}}$ & $1.98 \pm 0.11^{\text {Ba }}$ & $1.85 \pm 0.12^{\mathrm{Aa}}$ & $1.85 \pm 0.12^{\text {Aa }}$ & & & \\
\hline \multirow{2}{*}{ RMSSD (ms) } & $\mathrm{N}$ & $1.85 \pm 0.23 \mathrm{Nm}$ & $1.85 \pm 0.23 \mathrm{Ca}$ & $1.77 \pm 0.23 \mathrm{BCa}$ & $1.70 \pm 0.23 \mathrm{ABa}$ & $1.65 \pm 0.22^{\mathrm{Aa}}$ & $1.67 \pm 0.23 \mathrm{ABa}$ & \multirow{2}{*}{0.088} & \multirow{2}{*}{$<0.001$} & \multirow{2}{*}{0.842} \\
\hline & $\mathrm{PH}$ & $1.67 \pm 0.32 \mathrm{Nm}$ & $1.67 \pm 0.32^{\mathrm{Ca}}$ & $1.62 \pm 0.21^{\mathrm{BCa}}$ & $1.52 \pm 0.24 \mathrm{Aa}$ & $1.49 \pm 0.20^{\mathrm{Aa}}$ & $1.54 \pm 0.21^{\mathrm{ABa}}$ & & & \\
\hline pNN50 (\%) & $\mathrm{N}$ & $1.58 \pm 0.35 \mathrm{Bb}$ & $1.58 \pm 0.35^{\mathrm{Bb}}$ & $1.30 \pm 0.33^{\mathrm{Aa}}$ & $1.20 \pm 0.52^{\mathrm{Aa}}$ & $1.19 \pm 0.51^{\mathrm{Aa}}$ & $1.17 \pm 0.71^{\mathrm{Aa}}$ & 0.140 & $<0.001$ & 0.371 \\
\hline
\end{tabular}

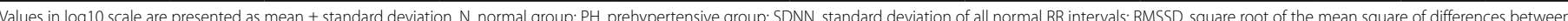

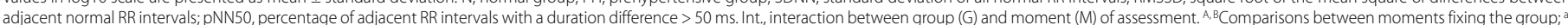
bComparisons between groups fixing the moment. Different letters reveal statistically significant differences $(\mathrm{p}<0.05)$ on two-way repeated measures analysis of variance complemented by the Bonferroni test.

Table 4. Measures of heart rate variability in the frequency domain, according to group and assessment moment.

\begin{tabular}{|c|c|c|c|c|c|c|c|c|c|c|}
\hline \multirow{2}{*}{ Variables } & \multirow{2}{*}{ Group } & \multicolumn{6}{|c|}{ Moments } & \multicolumn{3}{|c|}{ Factors ( $p$-value) } \\
\hline & & Rest & Test & $10 \mathrm{~min}$ & $20 \mathrm{~min}$ & $30 \mathrm{~min}$ & $40 \mathrm{~min}$ & G & M & Int. \\
\hline \multirow{2}{*}{ LF (nu) } & $\mathrm{N}$ & $3.05 \pm 0.31^{\mathrm{Aa}}$ & $3.30 \pm 0.30^{\mathrm{Ba}}$ & $3.16 \pm 0.40^{\mathrm{ABa}}$ & $3.14 \pm 0.33^{\mathrm{ABa}}$ & $3.17 \pm 0.31 \mathrm{ABa}$ & $3.25 \pm 0.30 \mathrm{ABa}$ & \multirow{2}{*}{0.827} & \multirow{2}{*}{0.001} & \multirow{2}{*}{0.732} \\
\hline & $\mathrm{PH}$ & $3.09 \pm 0.42^{\mathrm{Aa}}$ & $3.24 \pm 0.25^{\mathrm{Aa}}$ & $3.11 \pm 0.31^{\mathrm{Aa}}$ & $3.06 \pm 0.30^{\mathrm{Aa}}$ & $3.22 \pm 0.27^{\mathrm{Aa}}$ & $3.20 \pm 0.32^{\mathrm{Aa}}$ & & & \\
\hline \multirow{2}{*}{$H F(n u)$} & $\mathrm{N}$ & $3.24 \pm 0.53^{\mathrm{Ba}}$ & $3.01 \pm 0.50 \mathrm{ABa}$ & $2.86 \pm 0.58 \mathrm{Aa}$ & $2.77 \pm 0.45^{\mathrm{Aa}}$ & $2.81 \pm 0.51^{\mathrm{Aa}}$ & $2.84 \pm 0.45^{\mathrm{Aa}}$ & \multirow{2}{*}{0.203} & \multirow{2}{*}{$<0.001$} & \multirow{2}{*}{0.761} \\
\hline & $\mathrm{PH}$ & $2.90 \pm 0.58 \mathrm{Ca}$ & $2.84 \pm 0.41 \mathrm{BCa}$ & $2.59 \pm 0.52^{\mathrm{ABa}}$ & $2.51 \pm 0.39 \mathrm{Aa}$ & $2.65 \pm 0.42^{\mathrm{ABCa}}$ & $2.65 \pm 0.41 \mathrm{ABCa}$ & & & \\
\hline \multirow{2}{*}{$\mathrm{LF} / \mathrm{HF}$} & $\mathrm{N}$ & $-0.18 \pm 0.36 \mathrm{Aa}$ & $0.29 \pm 0.23^{\mathrm{Ba}}$ & $0.30 \pm 0.27^{\mathrm{Ba}}$ & $0.38 \pm 0.27 \mathrm{Ba}$ & $0.35 \pm 0.28^{\mathrm{Ba}}$ & $0.42 \pm 0.25^{\mathrm{Ba}}$ & \multirow{2}{*}{0.028} & \multirow{2}{*}{$<0.001$} & \multirow{2}{*}{0.207} \\
\hline & $\mathrm{PH}$ & $0.18 \pm 0.29^{A} b$ & $0.41 \pm 0.25^{\mathrm{Ba}}$ & $0.52 \pm 0.26^{\mathrm{Ba}}$ & $0.56 \pm 0.23 \mathrm{Ba}$ & $0.57 \pm 0.24 \mathrm{Ba}$ & $0.55 \pm 0.31^{\mathrm{Ba}}$ & & & \\
\hline \multirow{2}{*}{ VLF (nu) } & $\mathrm{N}$ & $3.28 \pm 0.35^{\mathrm{Aa}}$ & $4.08 \pm 0.26 \mathrm{Ca}$ & $3.65 \pm 0.43^{\mathrm{Ba}}$ & $3.50 \pm 0.32^{\mathrm{ABa}}$ & $3.53 \pm 0.24 \mathrm{ABa}$ & $3.53 \pm 0.27^{\mathrm{Aba}}$ & \multirow{2}{*}{0.409} & \multirow{2}{*}{$<0.001$} & \multirow{2}{*}{0.322} \\
\hline & $\mathrm{PH}$ & $3.38 \pm 0.36^{\mathrm{Aa}}$ & $4.04 \pm 0.24 \mathrm{Ba}$ & $3.55 \pm 0.31^{\mathrm{Aa}}$ & $3.35 \pm 0.33^{\mathrm{Aa}}$ & $3.32 \pm 0.32^{\mathrm{Aa}}$ & $3.45 \pm 0.32^{\mathrm{Aa}}$ & & & \\
\hline
\end{tabular}

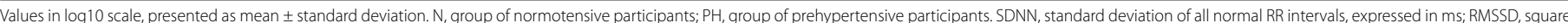

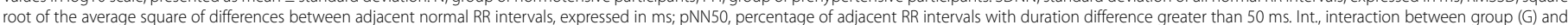

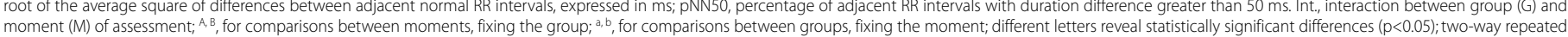
measures analysis of variance complemented by the Bonferroni test.

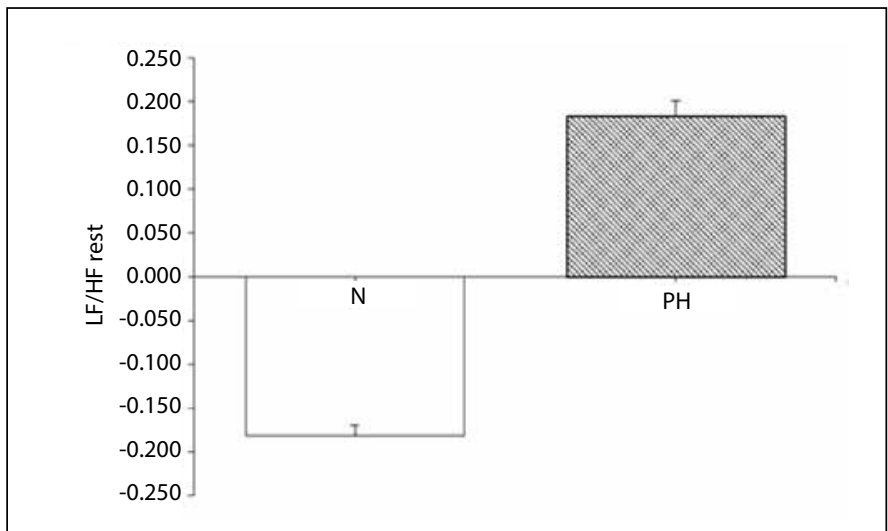

Figure 2. Adjusted measures of the relationship between components of low frequency (LF) and high frequency (HF) body fat by group. N, normal group; PH, prehypertensive group. Analysis of covariance used for the assessment ( $p>0.05$ ).

In our study, during the 1RM test, an increase in HR was observed as expected, albeit with significant intergroup differences (Table 1). At higher work rates, the stimulation of the sinoatrial and atrioventricular nodes of the sympathetic nervous system causes greater activation of the myocardial contraction, considerably increasing the HR during exercise. The volume of blood pumped by the heart depends on the increase in the demand for oxygen in the skeletal muscle, which is also responsible for the increase in $\mathrm{HR}^{4,22}$

A high persistence of HR was identified in the $\mathrm{PH}$ group after the maximum load test, corroborating data presented by Saldanha (2016), who described the adjustment of the muscle afferent sympathetic activity being influenced by the accumulation of adenosine, hydrogen ions, and other metabolites, preventing the reduction of the HR to pre-exercise levels. ${ }^{23}$

The DP behaved in a manner consistent with physical effort, increasing according to the load increment during the 1RM test and displaying significant differences only during the test (Table 2). The increase in DP is related with increased intensity and presents higher pressure in the prehypertensive condition than normal levels. ${ }^{23}$ There was an increase in DP and SBP but no increase in cardiovascular risk according to Fornitano and Godoy (2006), who evaluated 246 volunteers and proved the predictive value of DP as a safe tool in the prescription of exercise. ${ }^{24}$

Cornelissen and Smart (2013) demonstrated that short duration and high intensity resistance training reduces both SBP and DBP, which is also in agreement with the findings of the present study, although elevated SBP and DBP levels were observed during the experiment (Table 2) due to acute sympathetic action and posterior vagal predominance as a result of the stimulus of the $1 \mathrm{RM}$ test. ${ }^{25}$

Given the HRV results, the importance and significance of many measures are complex and there is a tendency toward incorrect conclusions and excessive or unfounded extrapolations. Accordingly, a team formed by the European Society of Cardiology and the North American Society for Electrophysiological Stimulation published recommendations to standardize the nomenclature and develop term definitions, specify standard measurement methods, define pathophysiological correlations, describe currently appropriate clinical applications, and identify areas for future research. ${ }^{26}$

An increase or reduction in HRV indicates a change in the sympathetic-vagal balance in which a high HRV indicates proper functioning of autonomic control. ${ }^{12,26-28}$ In this study, no statistically significant intergroup differences in SDNN and RMSSD were identified during rest or in the acute response to the $1 \mathrm{RM}$ test despite lower expected autonomic modulation rates in the normotensive condition compared to the prehypertensive condition. In contrast, Paschoa et al. (2006) reported a reduction in the SDNN and RMSSD indices in normotensive individuals after strength exercises. ${ }^{27}$ The pNN50 variable was reduced in the prehypertensive state at rest, i.e., increased sympathetic stimulation in the pre-exercise condition that remained unchanged after the test, demonstrating that the prehypertension condition is associated with a reduced HRV. ${ }^{28}$ In the frequency domain, in which there is a real possibility of demonstrating the sympathetic-vagal balance on the heart, a difference during rest in 
the variable LF/HF was identified with a predominance of the sympathetic system in the PH group, consistent with findings of published reports. 12,27,28

No difference was observed in the behavior of the variable LF/HF after the adjustment of HRV to body fat indices. ${ }^{26-29}$ However, the relationship between obesity and autonomic dysfunction seems dependent on the obesity indicator used. When waist circumference and waist-to-hip ratio were used as indicators, they were associated with changes in autonomic modulation, while BMI was not significantly correlated. ${ }^{29}$ The reduction of the variable pNN50 (vagal) was explained due to the component exercise that provoked the sympathetic action with a consequent reduction of the vagal component. Future studies could more objectively use the LF/HF ratio in the frequency domain and the pNN50 index in the time domain with clinical applicability in the prescription of exercise when this is associated with hemodynamic assessment, since they are equivalent and in agreement with the study of the European Society of Cardiology and the American Society of Applied Electrophysiology. ${ }^{26}$

The present study assessed the cardiovascular responses in the 1RM test in a prehypertensive population, which has been rarely applied in environments that use exercise prescriptions. Thus, the quest to understand the acute behavior of HR and HRV during maximal exertion and recovery in the 1RM test aims to facilitate the prescription of this type of exercise to this population, opening up the opportunity for studies with other populations of female patients and/or those with other cardiovascular risk factors.

In terms of social tangibility, one identifies the breakdown of the paradigm that individuals whose BP level change cannot perform strength exercises. In this study, both normotensive and prehypertensive responsiveness in the reduction of BP levels were observed after the 1 RM test, pointing to the safety of its applicability by prescribers of resisted exercise since it is more applicable to the general population.

\section{CONCLUSION}

Our findings demonstrated that the 1RM test promoted greater cardiovascular responses in the PH group than in the $\mathrm{N}$ group. However, the analysis of $B P$ and DP revealed that the 1 RM test did not result in an increased cardiovascular risk in PH individuals than in N individuals. In general, autonomic modulation, with respect to the time and frequency domains, was similar between the normotensive and prehypertensive groups.

All authors declare no potential conflict of interest related to this article

AUTHORS' CONTRIBUTIONS: Each author made significant individual contributions to this manuscript. CDL (0000-0003-0480-8990)*: intellectual concept, literature search, collection, analysis, writing and revision; SAOJ (0000-0002-8895-9456)*: supervision, statistical analysis and intellectual concept; PFM (0000-0001-9477-3386)*: data analysis, literature search and writing; CSM (0000-0001-5637-7569)*: data analysis, writing; FSSB (0000- 0002-2072- 4853)*: data analysis and revision; GEO (0000-0001- 8862- 945X)*: statistical analysis, data analysis and revision of the manuscript. ${ }^{*} \mathrm{ORCID}$ (Open Researcher and Contributor ID).

\section{REFERENCES}

1. Olbrich SR, Nitsche MJT, Olbrich Neto J, Mori NLR. Sedentarismo: prevalência e associação de fatores de risco cardiovascular. Revista Ciência em Extensão. 2010;5(2):30-41.

2. Nobre F. Valores de pressão arterial para o diagnóstico e metas: análise crítica das diretrizes mais recentes. Rev Soc Cardiol. 2015;25(1):19-22.

3. Malachias MVB, Souza WKSB, Plavnik FL, Rodrigues CIS, Brandão AA, Neves MFT, et al. $7^{\text {a }}$ Diretriz Brasileira de Hipertensão Arterial. Arq Bras Cardiol. 2016;107(3):10-3.

4. Santos EMR, Gomes TM, Fares Júnior RS, Novaes JS. Respostas cardiovasculares agudas em diferentes exercícios de força. Rev SOCERJ. 2008;21(3):166-72.

5. Forjaz CLM, Rezk CC, Melo CM, Santos DA, Teixeira L, Nery SS, et al. Exercício resistido para o paciente hipertenso: indicação ou contra-indicação. Rev Bras Hipertens. 2003;10(2):119-24.

6. Fleck SJ, KraemerWJ. Fundamentos do Treinamento de Força Muscular. 3nd ed. Porto Alegre: Artmed; 2006.

7. Castinheiras-Neto AG, Costa-Filho IR, Farinatti PTV. Respostas cardiovasculares ao exercício resistido são afetadas pela carga e intervalos entre séries. Arq Bras Cardiol. 2010;95(4):493-501.

8. Terra DF, Mota MR, Rabelo HT, Bezerra LMA, Lima RM, Ribeiro AG, et al. Redução da pressão arterial e do duplo produto de repouso após treinamento resistido em idosas hipertensas. Arq Bras Cardiol. 2008;91(5):299-305

9. Polito MD, Farinatti PT, Lira VA, Nóbrega AC. Blood Pressure assessment during resistance exercise: comparison between auscultation and Finapres. Blood Press Monit. 2007;12(2):81-6.

10. Lancha Júnior AH, Lancha LOP. Avaliação e prescrição de exercícios físicos: normas e diretrizes. São Paulo: Manole Conteúdo; 2016.

11. Sousa PFM, Pinheiro F, Monge D, Pires FO. Pressão arterial e PSE em múltiplas séries de exercício resistido de diferentes intensidades. R Bras Ci Mov. 2010;18(4):26-33

12. Lopes PFF, Oliveira MIB, André SMS, Nascimento DLA, Silva CSS, Rebouças GM, et al. Aplicabilidade Clínica da Variabilidade da Frequência Cardíaca. Rev Neuroc. 2013;21(4):600-3.

13. Beck DT, Martin JS, Casey DP, Braith RW. Exercise training improves endothelial function in resistance arteries of young prehypertensives. J Hum Hypertens. 2014;28(5):303-9.

14. Pescatello LS, Franklin BA, Fagard R, FarquharWB, Kelley GA, Ray CA. American College of Sports Medicine. Exercise and hypertension. Med Sci Sports Exerc. 2004;36(3):533-53.

15. Shepard RJ. PAR-Q, Canadian home fitness test and exercise screening alternatives. Sports Medicine. 1988;5(3):185-95.

16. Brzycki M. Strength testing-predicting a one-rep max from repetitions to fatigue. JOPERD. 1993;64(1):88-90.
17. Kraemer WJ, Fleck SJ, Deschenes MR. Fisiologia do exercício: teoria e prática. Rio de Janeiro: Guanabara Koogan; 2013.

18. Rodrigues Júnior FF, Aguiar AP, Carneiro RFV, Lima DLF, Loureiro ACC. Análise de protocolos de testes de força submáximos para predição de carga máxima (1RM) na musculação. Coleção Pesquisa em Educação Física. 2012;11(2):7-14.

19. Zanetti HR, Ferreira AL, Haddad EG, Gonçalves A, Jesus LF, Lopes LTP. Análise das respostas cardiovasculares agudas ao exercício resistido em diferentes intervalos de recuperação. Rev Bras Med Esporte. 2013;19(3):168-70.

20. Boutcher YN, Boutcher SH. Exercise intensity and hypertension: what's new? J Hum Hypertens. 2017;31(3):157-64.

21. Maior AS, Gonçalves R, Marocolo M. Resposta Aguda da Pressão Arterial, da Frequência Cardíaca e do Duplo-Produto após uma Sessão de Eletroestimulação em Exercícios de Força. Revista da SOCERJ. 2007;20(1):28-34

22. Farinatti PTV, Assis BFCB. Estudo da frequência cardíaca, pressão e duplo-produto em exercício contra-resistência e aeróbio contínuo. Rev Bras Ativ Fis Saúde. 2000;5(2):5-16

23. Saldanha MA, Vilaça-Alves J, Rodrigues-Neto G, Novaes JS, Saavedra F, Reis VM, et al. Acute effect of resistance exercise performed at different intensities on the hemodynamics of normotensive men. Motricidade. 2016;12(1):60-8.

24. Fornitano LD, Godoy MF. Duplo produto elevado como preditor de ausência de coronariopatia obstrutiva de grau importante em pacientes com teste ergométrico positivo. Arq. Bras. Cardiol. 2006;86(2):138-44

25. Cornelissen VA, Smart NA. Exercise Training for Blood Pressure: A Systematic Review and Meta-analysis. J Am Heart Assoc. 2013;2(1):e004473.

26. Task Force of the European Society of Cardiology; the North American Society of Pacing Electrophysiology. Heart Rate Variability: Standards of Measurement, Physiological Interpretation, and Clinical Use. Circulation. 1996:93(5):1043-65.

27. Paschoa DC, Coutinho JFS, Almeida MB. Análise da Variabilidade da Frequência Cardíaca no Exercício de Força. Revista da SOCERJ. 2006;19(5):385-90.

28. Paschoal MA, Volanti VM, Pires CS, Fernandes FC. Variabilidade da frequência cardíaca em diferentes faixas etárias. Rev bras fisioter. 2006;10(4):413-9.

29. Farah BQ, Prado WL, Tenório TRS, Ritti-Dias RM. Relação entre variabilidade da frequência cardíaca e indicadores de obesidade central e geral em adolescentes obesos normotensos. Einstein. 2013;11(3):285-90 